Notes and Queries (2015) 62 (1):92-93.

doi: $10.1093 /$ notesj/gju225

First published online: January 25, 2015

\title{
SHAKESPEARE'S 'HONEY-STALKS'
}

David Kathman's list of dialect words from Warwickshire and the West Midlands in

Shakespeare Beyond Doubt includes 'honey-stalks' for clover.' ${ }^{1}$ Closer analysis reveals that this word is not Warwickshire dialect but was coined by Shakespeare and that it does not have the meaning commonly assumed.

In Titus Andronicus, Tamora says:

I will enchant the old Andronicus

With words more sweet, and yet more dangerous, Than baits to fish, or honey-stalks to sheep, When as the one is wounded with the bait, The other rotted with delicious feed.

According to the $O E D$ - and confirmed by a search of digitized works on Early English Books Online - Shakespeare is the only writer to use the phrase 'honey-stalks' to mean ‘clover blossom'. So how was this meaning derived? Bruce Thomas Boehrer has traced its origin to Samuel Johnson's 1765 edition of Shakespeare's Dramatick Works, where Johnson provides the gloss "Honey-stalks are clover flowers, which contain a sweet juice. It is common for cattle to overcharge themselves with clover, and so die". This has been accepted by both the $O E D$ and Shakespeare's subsequent editors, though Johnson's contemporary, John Monck Mason, objected:

"Clover has the effect that Johnson mentions, on black cattle but not on sheep. Besides, these honey-stalks, whatever they may be, are described

${ }^{1}$ D. Kathman, 'Shakespeare and Warwickshire', in Shakespeare Beyond Doubt, ed. Wells and Edmonson, (Cambridge, 2013), 129. 
as rotting the sheep, not as bursting them, whereas clover is the wholesomest food you can give them". ${ }^{2}$

Boehrer's research into English husbandry manuals of the period reveals that the suspected cause of sheep-rot in Shakespeare's era was the eating of grass laden with a type of dew known then as 'Honey Dew'. As he puts it, 'Honey-stalks' is "a convenient nonce formulation referring to any vegetation laden with honeydew and therefore noxious to sheep." 3 That Shakespeare is the only writer to use the phrase is a strong argument for its being his own invention. Its appearance at the end of the nineteenth century in Joseph Wright's English Dialect Dictionary as a name for "the blossoms of white clover", and its designation as Warwickshire dialect, thus stems entirely from its use in Titus Andronicus, Samuel Johnson's (mistaken) gloss, and the general presumption that the author hailed from Warwickshire. To refer to the $E D D$ as proof that the word is Warwickshire dialect constitutes circular reasoning.

ROSALIND BARBER Goldsmiths, University of London.

2 J. M. Mason, Comments on the Last Edition of Shakespeare's Plays (London, 1785), 306.

${ }^{3}$ B. T. Boehrer, Animal Characters: Non-human Beings in Early Modern Literature (Philadelphia, 2010), 178. 